\title{
Reflexões sobre o confinamento e o distan- ciamento social em tempos de pandemia
}

\author{
https://doi.org/10.21814/uminho.ed.23.4
}

\section{Jean-Martin Rabot}

Jean-Martin Rabot (ORCID: 0000-0001-7688-3186) é Professor Associado do Instituto de Ciências Sociais da Universidade do Minho e investigador do Centro de Estudos de Comunicação e Sociedade (CECS). Doutorado em Sociologia, os seus trabalhos incidem sobre a sociologia clássica, a sociologia do imaginário, os Estudos Culturais e as novas tecnologias. Ultimamente, tem-se debruçado sobre a análise da crise económico-financeira de 2007/2008, na perspetiva da sociologia do imaginário desenvolvida por Gilbert Durand e Michel Maffesoli. 
«Homero é novo, esta manhã, e talvez nada seja tão velbo como o jornal de hoje». (Péguy, 1934, p. 52)

\section{A INDESTRONÁVEL SOCIABILIDADE DO HOMEM}

A epidemia do coronavírus veio bater à nossa porta e rapidamente se metamorfoseou em pandemia. O coronavírus não fez mais do que seguir os caminhos pelos quais os homens enveredaram. Foram eles, através dos seus incessantes e frenéticos movimentos, que o difundiram nos quatro cantos deste mundo. A resposta foi tão global quanto o foi o contágio. Seguindo à letra as recomendações da Organização Mundial da Saúde, inúmeros países decretaram o estado de emergência e impuseram medidas de contenção, nomeadamente o confinamento das populações e o distanciamento social entre pessoas. É como se os homens se tornassem estrangeiros para si próprios. Acabaram por interiorizar e incorporar nos seus hábitos estas medidas, a ponto de o contágio pelo medo se tornar mais corrosivo do que o contágio pelo próprio vírus. No entanto, a natureza social do Homem não se deixou afetar nem infetar pela ideologia reinante. O presente coronavírus não pôs fim ao que Arthur Schopenhauer chamava o «querer viver» do Homem, nem à sua «fome de pele» (López, 2020), nem mesmo à sua vontade de partilhar com os outros sentimentos comuns.

Numa guerra, e as metáforas guerreiras não faltam quando evocamos o novo coronavírus, existem sempre vítimas colaterais. Não estamos a referir-nos às populações civis, nem às camadas mais desfavorecidas da sociedade, mas à própria vida social e às próprias relações sociais.

A fragilização dos laços sociais não é assunto novo para os sociólogos. Zygmunt Bauman entendia como líquidas as instituições e as relaçôes sociais atuais, quer se trate do amor, do Estado, da moral ou dos contratos, para realçar o seu caráter efémero. E quase cem anos antes de Bauman, Simmel já tinha estabelecido uma correspondência entre a liquidez do dinheiro e o afrouxamento das relaçóes pessoa a pessoa. Simmel mostrou que o dinheiro, enquanto símbolo abstrato de troca e enquanto equivalente geral, atuou em dois sentidos, simultaneamente diferentes e complementares. Ao mesmo tempo que libertou os servos da subordinação aos senhores e das antigas 
relaçóes pessoais, o dinheiro tornou os homens modernos mais dependentes dos processos de abstração e de despersonalização da nova economia monetária, e, por conseguinte, mais individualistas. Sendo «um meio para tudo» (Simmel, 1987, p. 548), o dinheiro fez com que «todos os aspetos afetivos tivessem desaparecido da perceção dos processos naturais e tivessem sido substituídos pela inteligência única e objetiva» e que fossem excluídas também «as intervenções do sentimento que apenas se inserem nos pontos terminais da corrente teleológica; já não são mais do que objetos da inteligência, que nos guiam na sua utilização» (ibid.). Por outras palavras, a afetividade e os sentimentos inscrevem-se no processo de intelectualização da vida, encontrando-se reduzidos ao estatuto de mero meio de realização da objetividade. Max Weber, por sua vez, encarou o individualismo moderno como consequência de um processo que denominou de racionalização da vida e de desencantamento do mundo.

Daí que alguns autores tenham assimilado as presentes medidas de confinamento e de distanciamento social a uma tendência pré-existente na sociedade, que caracteriza o individualismo da modernidade, à semelhança da romancista franco-marroquina Leilla Slimani (2020), para a qual: «Todos os estudos o comprovam: tocamos cada vez menos na pele do outro. Olhando bem, o que mais acariciamos ao longo do dia é provavelmente o ecrã do nosso telemóvel».

$\mathrm{Na}$ realidade, existem épocas (etimologicamente: parênteses), em que a vida social é mais diluída e outras em que, pelo contrário, se manifesta na plenitude da sua força. Assim como o indicou o historiador francês Georges Duby, do fim do império romano até ao ano mil, o campo sobrepôs-se às cidades. Estas não eram mais do que vestígios de um passado glorioso, meros «esqueletos ressequidos de uma cidade romana» (Duby, 1976, p. 11), enquanto que os camponeses, isolados e confinados, lutando pela sobrevivência, não passavam de «escravos da fome» (ibid., p. 12).

O período atual de pandemia assemelha-se a um retorno à barbárie de épocas que, em virtude da nossa crença na ideologia do progresso, pensávamos ter definitivamente superado. Esse retorno à barbárie é particularmente insidioso, na medida em que está rodeado de um sofisticado aparelho de justificaçóes, entre as quais a preponderância dada à preservação da vida humana em relação aos imperativos económicos da produtividade e da competitividade. Em contrapartida, sacrificou-se a vida social: 
as formas de socialização que florescem à volta de uma mesa e de uns copos; as relações sexuais fora do casamento e a concubinagem; as cerimónias religiosas; a discussão passional da coisa pública; os rituais políticos, como os ajuntamentos dos coletes amarelos nas rotundas da periferia das cidades; as festas juvenis; os ajuntamentos musicais; as procissões dominicais, em família ou entre amigos, nas largas avenidas dos centros comerciais; os encontros desportivos, etc. As afinidades eletivas passaram a ser afinidades conectivas, para utilizar a expressão do sociólogo Vincenzo Susca (2016). Ora, o facto de o confinamento e de o distanciamento serem remediáveis, superáveis ou sublimáveis pela utilização das novas tecnologias, não implica a sua aceitação beata. É nesse sentido que Edgar Morin afirma: «Os Skype e os Zoom não dão o contacto carnal, o som do copo ao fazer um brinde. A comida doméstica, por excelente que seja, não suprime o desejo de restaurante. (...) A redução ao indispensável dá também a sede do supérfluo» (Morin, 2020, p. 415).

Longa é, no entanto, a lista dos ajuntamentos proibidos, em nome da salubridade pública e do bem-estar individual. Como no-lo diz o filósofo Emanuele Coccia, numa entrevista concedida ao jornal Le Monde: «É a cidade que, de repente, desapareceu ou, para o dizer melhor, foi retirada, subtraída ao uso: jaz à nossa frente, como se estivesse na montra de uma loja. (...) A população encontrou-se abandonada em frente deste enorme vazio, chora a cidade desaparecida, a comunidade suspensa, a sociedade fechada, com as suas lojas, as suas universidades, os seus estádios: as lives do Instagram, os aplausos ou os cantos coletivos nas varandas, a multiplicação arbitrária e alegre do jogging semanal representam antes de mais rituais de elaboração do luto, tentativas desesperadas de reproduzi-la em miniatura».

$\mathrm{Na}$ realidade, podemos aplicar à sociabilidade dos tempos da pandemia a seguinte sentença romana: Fluctuat nec mergitur, ou seja, é sacudido pelas ondas, mas [o barco] não afunda.

\section{CIÊNCIA, POLÍTICA E PODER}

Com o aparecimento do coronavírus, os cientistas foram projetados para a frente da cena mediática e chegaram mesmo a gozar de uma fama à qual não estavam 
habituados. E mais, chegaram a gozar de um certo protagonismo em matéria de aconselhamento político. Com efeito, vimos, ao longo dos últimos meses, que os governos europeus tomaram as decisóes que diziam respeito à vida quotidiana dos cidadãos dos diferentes Estados, consultando previamente os cientistas, neste caso os médicos especializados em virologia, em infeciologia, em imunologia e em epidemiologia. Em França, pelo menos dois agrupamentos de peritos, o «Conselho Científico» e o «Comité de Análise, Investigação e Perícia» (Comité Analyse, Recherche et Expertise, CARE) tinham por missão esclarecer os poderes públicos, prodigando-lhes informações constantes sobre a evolução da epidemia e conselhos para remediar a crise sanitária.

A presente crise sanitária parece apresentar muitas afinidades com a crise dos subprime surgida em 2007/2008, quando todas as decisões foram tomadas pelos ministros das finanças e os peritos em matéria de economia. $\mathrm{O}$ fracasso das medidas de austeridade que eram apresentadas como a panaceia ao problema dos endividamentos dos Estados, como se as causas da crise se resumissem a esta única questão e não contemplassem a questão dos créditos hipotecários imobiliários e da dívida privada, da especulação e dos investimentos tóxicos, mostram claramente que nunca poderá existir uma via única na resolução das crises, sejam elas de ordem sanitária, económica ou outra. A própria palavra crise contradiz a ideia de uma via única e de uma solução única. Etimologicamente, a crise remete para o juízo que deve ser emitido num momento crítico e, por conseguinte, a decisão que deve ser tomada no momento oportuno, o kairós, entre muitas possíveis. Em grego, krisis significa distinguir com juízo, o infinitivo krinein exprime a separação e a decisão e o substantivo krinau remete para a triagem pelo crivo. Se a austeridade decorrente da crise dos subprime apresenta tantas similitudes com o confinamento da presente crise sanitária, é porque resulta de uma imposição unilateral, por parte de peritos, que se acham os detentores do saber, fazendo dele um instrumento de poder, esquecendo-se por completo da complexidade da realidade social. Tanto a austeridade como o confinamento falharam, pois embateram contra a aceitabilidade social das medidas tomadas. A primeira trouxe consigo um empobrecimento geral das populações e uma lassitude generalizada das pessoas, pouco propícios ao investimento. E o segundo teve como consequência um desmoronamento global das relaçôes sociais, às quais sucederam comportamentos de risco deliberadamente assumidos, atitudes de 
provocação às autoridades e de transgressão das regras. O que faltou em ambos os casos, à crise económico-financeira de 2007/2008 e à crise sanitária de 2020, foi a confiança (de fides, fé) - a fé nos outros.

O coronavírus veio servir os desígnios dos poderes políticos e científicos: divide et impera, dividir para reinar. Veio muito oportunamente conferir uma certa legitimidade aos grandes discursos, que desde o início da era pós-moderna, a partir dos anos sessenta do século passado, entraram em colapso. Veio dar um rude golpe à contestação de todas as formas de absolutismo, sejam elas o da razão ou o do Homem. Pois, com as descobertas científicas, próprias do Renascimento, e a ideologia do progresso, comum aos filósofos das Luzes, a história tem sido concebida como um avanço civilizacional contínuo, que deveria conduzir todos os homens para o fastígio do império da felicidade. O progresso baniria todos os flagelos da terra. A humanidade estava a caminho da perfeição, até agora reservada a Deus. Soprava um vento a tal ponto emancipador que «a história se tornou profética, a economia visionária, a sociologia divinatória, a psicologia conquistadora e a técnica demoníaca» (Freund, 1965, p. 756). Hoje em dia, a utopia da perfeição materializou-se nas crenças milenaristas dos trans-humanistas que anteveem a possibilidade e mesmo a necessidade «de melhorar a resistência do organismo humano à velhice, de aumentar as suas capacidades percetivas, intelectuais, e até de dotar a espécie humana, por hibridação, de aptidóes superiores em todos os compartimentos do jogo da vida» (Ferry, 2016, p. 62).

Entre os dirigentes do Google (do vocábulo matemático Googol, número cuja representação decimal se escreve com o número 1 seguido de 100 zeros!), muitos acreditam que, num futuro mais ou menos próximo, será possível ao Homem viver 1000 anos e que até será possível «eutanasiar a morte», segundo a expressão dos adeptos da referida firma do Silicon Valley, da qual o seu eminente engenheiro-chefe, Ray Kurzweil, é dos expoentes máximos (citada em Alexandre, Besnier, 2016, p. 64). A exclamação, sob forma de pergunta, de São Paulo está prestes a tornar-se realidade: «Onde está, ó Morte, a tua vitória? Onde está, ó Morte, o teu aguilhão?» (1 Coríntios 15). Mas os factos são teimosos e a realidade acaba sempre por se sobrepor aos sonhos dos utopistas (de ou-tópos, o que não existe, em lugar nenhum). A história não é tão linear quanto o desejariam os fervorosos crentes nos milénios (mil anos de vida, de prosperidade, de 
paz, etc.). Daí que as projeções trans-humanistas se inscrevam na ciclicidade e na redundância do mito. Podemos ver nelas uma reminiscência da procura da imortalidade por Gilgamés, o rei da Suméria, na antiga Mesopotâmia, ou ainda do mito de Asclépio, que Zeus matou com um raio, fazendo-o renascer a seguir. Com os mitos, redescobrimos uma verdade de bom senso, a de que não existe progresso sem regresso ou até sem regressão, a de que a história é cíclica, como o sugere a ideia de um eterno retorno em Nietzsche, ideia que este tinha metaforizada por meio das imagens do anel, do círculo, da bola e da roda. Como no-lo diz precisamente Nietzsche: «Curvo é o caminho da eternidade» (2013, p. 262).

A desconfiança em relação à política e às instituições sanitárias não é nova, mas ela ficou exacerbada com a crise da COVID-19. Vários elementos contribuíram para o agravamento desta desconfiança, como resultante da distância existente entre os cidadãos e os seus representantes a nível político e também a nível dos profissionais da saúde, em particular os médicos, cuja legitimidade provinha das únicas experimentação e prova científicas. A começar pela pouca recetividade do discurso científico pelo povo. Alguns pensadores, que poderíamos também denominar como psicólogos das profundezas, bem evidenciaram o hiato existente entre a verdade científica e as verdades existenciais, que são as do senso comum. Diz Weber: «A crença no valor da verdade científica é um produto de certas civilizações e não um dado da natureza» (1965, p. 211); ou ainda: «É verdade unicamente aquela que pretende valer para todos aqueles que querem a verdade» (ibid., p. 177). Diz Nietzsche: «É necessário que algo seja tido como verdadeiro, mas não é necessário, de forma alguma, que esse algo seja verdadeiro» (1930, T. 2, p. 18). Diz Pessoa, que podemos apelidar de Nietzsche português: «A ciência não curará muitos vícios, mas também não provoca nenhuns» (2003, p. 251).

Aliás, muitas controvérsias acerca das causas e da evolução da pandemia, da oportunidade das medidas a tomar, opuseram os especialistas entre si. Ilustrativos desta realidade foram os debates sobre a utilidade do confinamento e do uso das máscaras, principalmente na fase inicial de desenvolvimento da doença, ou ainda o debate sobre a eficácia da Hidroxicloroquina, que opôs, em França, o ministro da saúde Olivier Véran ao virólogo e microbiologista de Marselha, Didier Raoult. O primeiro, incarnando a legalidade dos procedimentos institucionais em matéria científica, tais como a aprovação 
das medicações na base da comprovação da sua utilidade por meio de estudos estatísticos - do latim status, estado, estatuto, e do italiano statista, Homem de Estado, sendo essa a definiçãa que o Dicionário francês Le Robert, de 1981, nos oferece: «Estudo metódico dos factos sociais, por procedimentos numéricos, (classificações contagens, inventários quantificados, recenseamentos), destinado a informar e ajudar os governos» - e de experimentações conduzidas em grande escala, o segundo incarnando a legitimidade de uma medicina prática, aplicada no terreno, sendo ele partidário do bom senso terapêutico dos médicos, o que lhe valeu o epíteto de velho druida ou ainda de guru (Husson, 2020). Duas atitudes epistemológicas confrontam-se aqui: a primeira, que é a de Véran, remete para uma conceção rigorista da ciência, inteiramente virada para a resolução quase matemática das situações de crise, ou seja, das situações críticas, por meio de uma série de operações lógico-dedutivas, de experimentações e de verificações. Poderíamos falar, a esse propósito, com o sociólogo alemão Siegfried Kracauer, autor de um livro sobre O romance policial, publicado em 1925, do triunfo do «método sobre o desafio» (2001, p. 191). Com efeito, ao decifrar o romance policial, Kracauer diz-nos «que o seu assunto é a sociedade desrealizada que nasce da comunidade existencial, quando a ratio é nela erigida em absoluto» (ibid., p. 63). A segunda atitude, que é a de Raoult, apoia-se na conceção negativa da epistemologia popperiana de uma ciência que progride à medida que elimina os erros, de uma ciência que necessariamente erra, no duplo sentido desta palavra: cometer um erro e vaguear. Em todo o caso, estas dissensões, de ordem teórica e prática, são reveladoras «de uma desconexão entre a instituição científica e a opinião pública, e, mais particularmente, de uma incapacidade em fazer ouvir e aceitar as normas de administração da prova científica» (Boncourt, 2020).

Em nome da salubridade pública, a ciência colocou-se ao serviço do poder. As epidemias são os salva-vidas dos poderes, que encontram nelas um motivo e uma justificação para instaurar e generalizar uma política disciplinar e a sua contrapartida, uma sociedade disciplinada, a partir de mecanismos de controlo das comunidades e das pessoas, como o mostrou primorosamente Michel Foucault, o eminente filósofo francês: «para ver funcionar as disciplinas perfeitas, os governantes sonhavam com o estado de peste» (1975, p. 200). Foucault estabelece uma tipologia idealtípica dos poderes ao estudar a evolução em matéria de conceção e de tratamento das doenças, tomando 
como exemplos os da lepra e da peste. Nas formas diferenciadas de abordagem destas doenças, Foucault conjetura o nascimento da biopolítica, enquanto tomada de posse da vida das populações, isto é, dos indivíduos regidos por leis biológicas. A lepra leva a um processo de exclusão, em que o indivíduo é declarado civicamente morto. Simulacros de inumação dos doentes, que precediam à sua entrada na leprosaria, testemunham a sua morte social. A peste, pelo contrário, implica, na ótica de Foucault, um novo poder, o poder disciplinar, que consiste numa técnica de gestão da vida e da morte das populaçôes, capaz de se aplicar aos territórios e de se insinuar nos corpos individuais. Por outras palavras, passámos de uma sociedade soberana, que ritualiza a morte, para uma sociedade disciplinar que procura maximizar a vida em nome do superior interesse nacional.

Foucault mostra, pois, como o tratamento diferenciado da lepra e da peste induziu um novo poder, o poder disciplinar. O leproso era excluído, enclausurado numa leprosaria, enquanto que o portador da peste era confinado: aplicava-se-lhe uma disciplina por parte dos poderes, uma disciplina que dizia respeito aos aspetos mais ínfimos e íntimos da sua vida, ao seu corpo, higiene, comportamento, etc., inaugurando assim a sociedade de controle. No primeiro caso, a morte social e física do sujeito é aceite com normalidade, até porque pode ser um meio de redenção. No segundo caso, dá-se ênfase à vida, à sobrevivência individual e coletiva, para salvaguardar o bom funcionamento das instituições e das atividades. Foucault acrescenta que os dois métodos de negociação com a realidade da doença e da morte, antinómicos no seu modo de funcionar, se aproximaram com o evoluir do tempo, até se confundirem nos dias de hoje. Neste sentido, aplicou-se ao espaço da exclusão, característico do tempo da lepra, a técnica da vigilância, do enquadramento, do adestramento e da quadriculagem disciplinar, uma técnica que se ajustava a toda a forma de marginalidade: aos pobres, aos loucos, aos bandidos e sobretudo aos mendigos e aos vagabundos, contra os quais Henry Ford, o magnata estadunidense da indústria automóvel, que pretendia transformar a sociedade numa linha de montagem perfeitamente articulada e racionalizada, travou uma guerra sem piedade. Para isso contribuíram as instituições, tais como os asilos, as escolas, as fábricas, as prisões, instituições essas que representavam o idealtipo de uma sociedade perfeita, uma sociedade de controlo 
ou de vigilância, capaz de separar de forma binária o indivíduo normal do indivíduo anormal, o ser produtivo do ser improdutivo, capaz também de circunscrever coercivamente o indivíduo, ao determinar quem é, ao atribuir-lhe sinais de reconhecimento, ao submetê-lo a uma forma de acompanhamento permanente.

O que os poderes político-sanitários visam é a interiorização, por parte da população, destas técnicas disciplinares. De facto, o sonho dos poderes sanitários é que nos tornemos «médicos de nós próprios», segundo a expressão do imunologista e presidente do Conseil Scientifique COVID-19, em França, Jean-François Delfraissy (Le Figaro, 2020), e o sonho dos poderes políticos é que fiquemos cientes do facto que, como diz o primeiro ministro português, António Costa, «cada um de nós tem de ser polícia de si mesmo» (Almeida, 2020). Com o desenvolvimento das novas tecnologias, a doença COVID-19 veio dar uma nova atualidade ao pensamento de Foucault, assim como um novo alento às ambições dos poderes político-sanitários. Com efeito, vemos, por exemplo, que na China centenas de milhóes de pessoas são vigiadas, por meio de técnicas de reconhecimento facial, via câmaras colocadas por todo o sítio; por meio de aparelhos que detetam a temperatura corporal à entrada dos prédios, das estações de comboio ou de metro, assim como nos edifícios públicos; por meio de aplicações móveis que permitem às autoridades sanitárias e políticas seguir (ou perseguir) os indivíduos nas suas deslocaçóes, estadias, encontros e convivências, reais ou virtuais, e que informam cada um, em tempo real, da presença de pessoas contaminadas em seu redor, meios esses que tornam totalmente anacrónicos os sofisticados e tão temidos métodos de vigilância e de repressão da Stasi, a antiga polícia política da Alemanha de Leste. Ou, como no-lo diz o historiador israelita Yuval Noah Harari (2020), a vigilância já não se processa sobre a pele, mas por-baixo-da-pele (under-the-skin): «Até agora, quando o seu dedo tocava no ecrã do seu smartphone e clicava num link, o governo queria saber exatamente em que é que estava a clicar. Porém, com o coronavírus, o foco de interesse mudou. Hoje em dia, o governo quer conhecer a temperatura do seu dedo e a pressão arterial por baixo da sua pele». 


\section{O SIGNIFICADO SOCIOLÓGICO DO CONFINAMENTO E DO DISTAN- CIAMENTO SOCIAL}

O confinamento dos indivíduos (de individuus, in-dividere, a unidade indecomponível, o que não pode ser dividido) e o distanciamento social caracterizam a modernidade, que se iniciou com o Renascimento e se prolongou com o Iluminismo do século XVIII, a revolução industrial do século XIX e os regimes quer democráticos quer totalitários dos séculos XX e XXI. Mais precisamente, o individualismo, a privacidade, a intimidade e os distanciamentos em relação aos outros resultam de um processo civilizacional, destacado por Norbert Elias (1989-1990), nomeadamente com a longa aprendizagem da domesticação dos comportamentos e dos costumes. Fazer abstração dos outros, contorná-los, evitar todo o contacto representavam outras tantas atitudes, que eram consubstanciais ao individualismo que decorreu deste processo civilizacional.

A pandemónica pandemia, que veio insinuar-se nas nossas vidas e separar os homens, não fez mais do que exacerbar uma tendência inaugurada pela modernidade. Como no-lo recorda Adorno, referindo-se a Goethe, a própria relação social teve como fundamento o desprendimento: «o tacto como a única saída permitindo salvaguardar as relaçóes entre homens alienados» (1983, p. 32). O tacto impôs-se ao contacto físico, mesmo que este não tenha desaparecido por completo do mapa das experiências humanas, como no-lo testemunham as cotoveladas, as pancadas e os empurróes sofridos nos centros comerciais e nos estádios de futebol, ou ainda quando observamos as relaçôes que os homens tecem com o divino, sendo que estes nunca se contentaram com a sua mera representação, procurando sempre experienciá-lo, vivenciá-lo ou tocar nele, como acontece nestes grandes centros de peregrinação que são Fátima, Santiago de Compostela ou Lourdes.

O confinamento e o distanciamento social atuais, que resultam das medidas de prevenção e de combate à nova epidemia de coronavírus (de epi-demos, por cima do povo, o que circula no povo), inscrevem-se, pois, numa tendência geral da sociedade ocidental. As medidas de confinamento e o distanciamento social que daí resulta foram impostos a mais da metade da humanidade, na base da instilação do medo e na base também da infantilização das pessoas, consideradas sempre no seu estado de menoridade, segundo a expressão do filósofo Kant, ou seja, como sendo incapazes de 
aceder ao estado de adulto, ao estado de maioridade, próprio da razão soberana, à autonomia (de auto-nomos, que encontra as normas em si mesmo), conferida pelo livre arbítrio. Para o século XVIII, trata-se de extrair toda a humanidade da «escravidão sem esperança» e da «eterna infância» (Condorcet, 1970, p. 209) por meio da razão. Ora, a submissão do indivíduo aos desígnios de uma razão sanitária e social, da qual os homens de ciência e os políticos seriam os únicos depositários, é talvez um «vírus que mata o espírito da democracia», como no-lo disse Joshua Mitchell (2020), numa entrevista concedida ao Le Figaro.

O isolamento nada tem de natural. No entanto, encontramo-lo abundantemente expresso nalguns romances, tais como Robinson Crusoé (2001, 1a ed. 1719), de Daniel Defoe; Sexta-feira ou os Limbos do Pacífico (1972, 1a ed. 1967), de Michel Tournier e inspirado no livro de Defoe; Vinte Mil Léguas Submarinas (1979, 1ae ed. 1869-1870), de Jules Verne; O Deserto dos Tártaros (2006, 1a ed. 1940), de Dino Buzzati. Encontrámo-lo também na própria vida social dos homens, tais como na tradição do monaquismo ou, contemporaneamente, nas chamadas telerrealidades, à semelhança do Big Brother.

Nestes exemplos de extremo isolamento social, o caráter social do Homem fica sempre salvaguardado. Robinson encontrou um alter ego, Sexta-feira, para o socializar e cristianizar segundo as normas do Ocidente, no romance de Defoe. Na adaptação do romance de Tournier, o papel de Robinson é de fazer de Sexta-feira um igual, e mesmo um irmão. No romance de Verne, o professor Aronnax e os seus dois co prisoneiros no Náutilus beneficiavam do contacto e dos conhecimentos do Capitão Nemo e dispunham de uma biblioteca de 12000 livros para conservarem uma ligação à humanidade. Drogo, o herói do romance de Buzzati, fechado num forte, situado no limiar de uma terra inculta, aproveitou a espera de um inimigo invisível, que não era mais do que a figura da sua própria morte, agarrando-se às rotinas da guarnição e aos rituais da vida quotidiana, de essência social.

No caso do confinamento voluntário nos conventos, os monges (de monos, só), enclausurados nas suas celas (palavra que deu origem à de célula, a unidade estrutural dos seres vivos), integram plenamente a comunidade de todos os cristãos, a comunhão dos santos, que inclui os vivos e os mortos e incarna uma forma de solidariedade que transcende os determinismos espácio-temporais. 
Por fim, nas telerrealidades, é por meio do confinamento dos indivíduos em espaços restritos e fechados que se processa a relação social. Pois, mesmo sendo premente nelas uma forma de egocentrismo bárbaro e de darwinismo social na luta pela sobrevivência, uma forma de panoptismo no controlo de todo o movimento, uma forma de obscenidade hiper-real na «proximidade absoluta», na «instantaneidade das coisas», na «sobre-exposição à transparência do mundo» (Baudrillard, 1987, p. 25), o indivíduo, por mais isolado que esteja, só existe em função do outro. No fundo, trata-se de inventar uma vida na qual cada um encontra o seu lugar, onde qualquer um se pode reconhecer nos outros, e isso constitui uma das premissas de toda a forma de socialização, como bem o viu Simmel, no seu texto: «Como é possível a sociedade?» (1999, p. 63-79).

No caso do confinamento e do distanciamento social, impostos em virtude da crise sanitária, em resposta à pandemia da COVID-19, as coisas não se processam de outra forma. É verdade que os gestos-barreira, como por exemplo o respeito de uma distância mínima de um a dois metros em relação ao outro, não propiciam um forte relacionamento social. Praticados mecanicamente e compulsivamente, estes gestos-barreira até inibem as raras pessoas desejosas de se aproximar dos outros e de transgredir as regras de o fazer. Os peritos - refiro-me aos políticos e aos médicos, e vimos que os primeiros se submeteram cegamente aos diagnósticos e às recomendaçóes dos segundos - incutiram o medo do outro nas pessoas, fazendo com que o encarássemos como uma ameaça e um perigo, ao ponto de que, na hora do desconfinamento, muitas pessoas tivessem preferido manter-se no isolamento, o que levou os psicólogos e os sociólogos a falarem de tentação do casulo, do síndroma da cabana ou ainda do síndroma do prisioneiro.

No entanto, o Homem é por natureza uma animal social, como o disse Aristóteles, há 2400 anos. Os comportamentos de afastamento do outro são, neste período de pandemia, meramente casuais e acabarão por desaparecer, mais cedo ou mais tarde.

Com a proscrição dos gestos familiares mais triviais, à semelhança do abraço, do beijo ou do aperto de mão, instauraram-se hábitos de desconfiança mútua, de medo recíproco, assim como manobras de evitamento do outro: «somos todos poluídos e poluidores potenciais», como no-lo diz Albertino Gonçalves (2020). Mas este distanciamento é 
mortífero, porque se faz em sentido único, sendo o resultado de uma imposição unilateral por parte das autoridades sanitárias e políticas. Não se trata de um distanciamento inerente a toda a vida social e proveniente da própria aproximação ao outro. O sociólogo canadiano Erving Goffman recordava-nos que o aperto de mão é um ritual de acesso ao outro, que confere ao indivíduo a possibilidade de se abrir ao outro e de resguardar-se dele, de criar um laço social ou de o desfazer. Neste sentido, o distanciamento e o evitamento não passam de rituais que respeitam o caráter sagrado do indivíduo. Devemos então ter em mira o facto de que a sociedade também consiste num «sistema de acordos de não ingerência» (Goffman, 1974, p. 56) na vida de outrem. São esses tipos de rituais e de acordos, livremente consentidos, que permitem aos indivíduos e aos grupos aos quais pertencem de interagir, segundo o esquema da conjunção e da disjunção (Octavio Paz), da unidade e da separação (Simmel), da atração e da repulsão (Maffesoli), tornando assim a vida social possível.

Com o alastrar da presente pandemia, os homens ficaram confinados (mais da metade da humanidade!), mas não socialmente finados. Basta ler o Diário de Adão, de Mark Twain, para percebermos que o Homem prescinde da perfeição do paraíso e da segurança da insulação: «Bendita seja a catástrofe que me uniu a ela [Eva]» (2001: 18, 1a ed. 1893). É assim que assistimos a múltiplas manifestaçóes coletivas que desafiaram as injunçôes dos cientistas e dos políticos. A imposição do confinamento, do distanciamento social e de gestos-barreira não deram cabo nem do espírito religioso, nem do espírito da festa, nem do espírito de revolta.

\section{O CONFINAMENTO, O DISTANCIAMENTO SOCIAL E O ESPÍRITO RELIGIOSO}

Tal como o nascimento e o nutrir-se, a morte não constitui apenas um facto biológico, mas antes um acontecimento social, que exige uma atuação coletiva, como o explicou o sociólogo francês Émile Durkheim. Ora, com o confinamento forçado, os homens foram privados da manifestação coletiva da sua espiritualidade. As igrejas foram fechadas, os cultos foram cancelados e as inumaçôes (de in-bumus, pôr em terra) tiveram que se realizar na mais estrita intimidade, quando não de forma anónima, sem familiares nenhuns. 
$\mathrm{Na}$ realidade, os rituais funerários representam atos sociais por excelência, transversais a toda a sociedade. As cerimónias fúnebres não são relíquias de um passado revoluto, mas exprimem a estreita ligação entre o aquém e o além, a imanência e a transcendência, o profano e o sagrado. Sendo o padre um intercessor entre Deus e os homens, um velório sem padre fica desprovido de todo o significado para o católico. Michel Maffesoli recorda-nos que católico procede de Katholon: «o que está em comum a todos e a tudo» (2020a, p. 319). A morte é precisamente um desses acontecimentos comum a todos e a tudo, um acontecimento que todos os homens, sem exceção, partilham. Sendo assim, para que o caráter irreversível da morte possa ser ultrapassado, esta tem que ser mediada: pela família, pelas instituiçóes religiosas, pela comunidade. É por meio dessa mediação que podemos lutar contra «a impressão de debilitação que o grupo sente quando perde um dos seus membros» (Durkheim, 1979, p. 574). É ainda por meio dessa mediação que podemos inscrever a morte na vida, fazer dela um destino, e assim dominar ou domesticar (de domus, casa, o que se torna familiar) o sofrimento que resulta da perda de um ente querido e o medo que decorre da irreversibilidade da separação. Por outras palavras, a dependência dos homens em relação à inexorabilidade da morte contribui para torná-los interdependentes. A reintrodução do trágico na vida propicia sempre mais-vida, segundo a expressão de Georg Simmel; é a condição do indomável «querer-viver», que encontramos cada vez que tomamos consciência da nossa finitude, como no-lo testemunham as épocas de decadência, à semelhança da Antiguidade Tardia, ou ainda todos os períodos submetidos aos flagelos destinais, quer se chamem fomes, guerras ou epidemias. Mais, é o reconhecimento do trágico da vida que permite encará-la como continuidade e como necessidade; é esse reconhecimento que outorga a união entre o instante histórico e a eternidade cósmica, a sublimação da doença e da decrepitude pela força vital e pela ebriedade do belo. É essa ideia que subjaz à maravilhosa obra de Thomas Mann: A Morte em Veneza, onde o decesso de Gustav von Aschenbach, levado pela epidemia de cólera, é concebido como a condição da perenidade da vida, na pessoa do jovem Tadzio, que incarna a «essência do belo, a forma enquanto pensamento divino, a única e pura perfeição que vive no espírito» (1978, p. 89). 
A atual epidemia de COVID-19 torna a colocar a questão da morte no centro do palco da vida. Assim como a necessidade de a domar por meio de uma ação coletiva, ou daquilo a que Maffesoli chama «“a experiencia afetiva” do sagrado» (2020a, p. 118): «A sabedoria do ensinamento da Igreja, na catena aurea da Tradição, foi a de recordar constantemente a consciência da morte: Sum moribundus, sou destinado a morrer. Um lembrete que está em consonância com aquilo a que chamaria "homeopatização" da morte, a da "boa morte”. Por este meio, instaura-se um poder-morrer, um saber-morrer, fazendo do trespasse uma passagem que eleva o ego individual» (ibid.).

É precisamente através dos rituais que a experiência afetiva do sagrado pode concretizar-se. Basta recordar os rituais funerários, como a toilette do defunto, praticados nas religiões muçulmana e judaica, rituais esses que foram proibidos. Ora, nestas religiões, trata-se de um «último dever» (Guénois, 2020) dos vivos em relação aos mortos. Pois, como no-lo disse magistralmente o pai fundador da sociologia, a sociabilidade reside mais na «continuidade sucessiva», do que na «solidariedade atual» (Comte, 1966, p. 79), sendo que é a primeira que determina a segunda e não o contrário. O culto que os vivos prestam aos mortos não é mais do que o reconhecimento da dependência dos primeiros em relação aos segundos: «Os vivos são sempre, e cada vez mais, necessariamente governados pelos mortos: tal é a lei fundamental da ordem humana» (ibid).

Esta fórmula aplica-se às civilizações passadas como às presentes. Pois, todas as religióes procuram incorporar a morte na vida e conceder um lugar aos mortos no mundo dos vivos. Assim, nos seus estudos sobre a cultura Dogon, o antropólogo Marcel Griaule mostrou que era por meio dos cultos prestados aos mortos, nomeadamente pela edificação de altares, que os vivos os reabilitavam, os integravam no mundo dos vivos, promovendo-os à «qualidade de ancestrais» (1966, p. 175). Os rituais fúnebres católicos, os últimos sacramentos, o velório, a missa do enterro - com a bênção e a purificação do morto - e o próprio enterro obedecem à mesma lógica de união entre os vivos e os mortos. Mesmo que, com o confinamento, as cerimónias fúnebres, à semelhança do velório e sobretudo da missa do enterro, que para o católico exprime a oração que a Igreja dirige a Cristo para a salvação da alma do defunto e para apoiar espiritualmente a família na hora da despedida, tenham sido reduzidas à sua expressão mais básica, 
vemos que as diferentes religióes souberam reinventar-se (de invenire, chamar ou atualizar aquilo que já existe), adaptar-se às novas condições impostas pelo confinamento: a celebração da Páscoa cristã e judaica, assim como a do Ramadão muçulmano, foram partilhadas nas redes sociais, procedendo-se dessa forma a uma reconstrução do laço social, abrindo um espaço para a expressão coletiva das emoções. Assim, foram celebradas missas no modo «drive in», com centenas de fiéis confinados nos seus automóveis, como aconteceu em França, na cidade de Châlons-en-Champagne, no domingo 17 de maio de 2020. Pois, como bem o apontou Vilfredo Pareto, o sociólogo italiano, a necessidade de exteriorizar os sentimentos constitui uma das manifestações fundamentais da natureza humana, à semelhança da exaltação religiosa, da qual diz que «não pertence a nenhuma religião, a nenhum povo, mas encontra-se na maior parte das religiões e na maior parte dos povos, às vezes de forma leve, às vezes de forma intensa» (1968, p. 580). É essa necessidade que certamente explica alguns extravasamentos por parte de padres que celebravam missas com a presença de fiéis, desobedecendo assim às medidas decretadas em virtude do estado de emergência, como aconteceu em Pedorido, Castelo de Paiva, no domingo 26 de abril de 2020.

\section{O CONFINAMENTO, O DISTANCIAMENTO SOCIAL E O ESPÍRITO FESTIVO}

As festas correspondem a uma rotura com a rotina do dia-a-dia, as obrigaçóes sociais e o trabalho. Permitem ao indivíduo sair do tempo profano para aceder ao tempo sagrado. Muitas vezes exprimem-se por meio da transgressão da ordem e mesmo da violência. Essa violência não pode ser julgada do ponto de vista da moral, mas do ponto de vista dos seus efeitos sobre a moral, dado que reforça o estar-junto no seio de uma determinada comunidade, como bem o constatou Durkheim, na obra "As formas elementares da vida religiosa”. Pois, a função principal das festas é a de aproximar as pessoas e de socializar os homens. Nos tempos da COVID-19, seria útil interrogarmo-nos sobre a utilidade de uma separação prolongada entre os seres. O distanciamento social é, por assim dizer, insuportável para todos aqueles que estavam a viver no regime da «intensificação da estimulação nervosa» (Simmel, 1979, p. 62), característico das metrópoles, no regime da fúria dionisíaca do consumerismo, no regime das vibrações dos 
festivais musicais, no regime do êxtase das raves, no regime dos tumultos dos recintos desportivos, no regime aglutinador do turismo de massa. Com efeito, inúmeras formas de ajuntamento proporcionam um hedonismo que só pode existir se for emocionalmente partilhado entre muitos.

É à luz deste hedonismo e desta partilha de emoções que vimos milhões de iranianos a festejarem o Noruz, o Ano Novo persa, que se estendeu de 20 de março a 04 de abril de 2020 e, para tal, a deslocarem-se de uma ponta do país para outra, com a finalidade de visitar os familiares e de passar uns dias de férias. É ainda sob o prisma do hedonismo e da partilha de emoções que vimos milhares de adeptos do PSG (Paris Saint-Germain Football Club) a festejarem na rua a vitória do seu clube sobre o Borussia Dortmund, em 11 de março de 2020, depois de um jogo realizado à porta fechada, com o objetivo de criar «uma atmosfera, um karma» (Commolet, 2020), segundo a expressão de um fã. E é sob esse mesmo prisma que vimos milhares de fãs a celebrarem o título da primeira liga inglesa de futebol, nas imediações do mítico estádio de Anfield, quando «tornaram o céu vermelho com os foguetes e cantaram o hino do clube "You'll Never Walk Alone” pela noite dentro» (Menezes, 2020).

Ainda no domínio deste desporto, podemos referir o jogo ilegal organizado entre dois bairros da cidade de Estrasburgo, os de Neuhof e de Hautepierre, que juntou 400 espetadores (quando os ajuntamentos de mais de 10 pessoas eram proibidos), em terreno neutro, no estádio Paco-Mateo de Koenigshoffen, jogo patrocinado, ou melhor dito, apadrinhado pela associação, com nome um tanto premonitório e provocatório nesses tempos de pandemia: «Joie et Santé Koenigshoffen (JSK)». Joie et santé, ou seja, alegria e saúde, não representam a mesma coisa, consoante se trata de pessoas que socializam, ao partilharem emoções a partir dos prazeres efémeros que a vida quotidiana lhes oferece, ou das autoridades locais, que não deixaram de denunciar uma «falta de responsabilidade» (Dernières Nouvelles d'Alsace, 2020). As alegações do presidente da Câmara de Póvoa de Varzim, vilipendiando «o comportamento inconsciente» (Castro, 2020) dos seus concidadãos, quando estes se juntaram em massa na Marginal da cidade, inscrevem-se também na lógica do saber-poder que as elites pretendem impor ao povo. 
É à luz do hedonismo, ainda, que vimos uma multidão de jovens a festejarem o «Spring Break», nas praias da Flórida, com o lema: «vamos todos morrer, mais vale acabar em beleza» (Le Nouvel Obs, 2020). É nesse mesmo sentido ainda que dezenas de parisienses dançaram na rua, no sábado 25 de abril de 2020, ao ritmo de uma canção do ícone musical dos anos setenta/oitenta, a já desaparecida Dalida, uma canção precisamente intitulada: «deixai-me dançar», com um desprezo e um desrespeito total por todas as medidas de coação. Da mesma forma, na Inglaterra, «os jovens "socialmente famintos" » anunciaram às autoridades um «verão de delírio» (Pidd, 2020), com a promessa da organização de múltiplas raves ilegais, se as medidas de contenção não forem aliviadas ou até suprimidas.

Temos plenamente consciência de que a multiplicação e a acumulação de exemplos não conferem solidez à lógica argumentativa, mas de que são representativos da invariável natureza humana e daquilo a que São Tomás de Aquino chamava o babitus. Este resulta da reiteração de usos e de costumes, da sedimentação de elementos que os homens têm em comum e que se convertem em disposiçóes para o futuro, em maneiras de estar que se ajustam em função dos lugares e das épocas. É por meio do babitus que as relações que os homens tecem com a natureza e entre eles se podem harmonizar. É assim que Tomás de Aquino afirma que «chamam-se disposiçóes ou babitus a saúde, a beleza e semelhantes coisas que implicam determinadas proporçôes de várias coisas, suscetíveis de serem combinadas diversamente» (Thomas, 1856, questão 49, p. 317). É ainda por meio do habitus, ou seja, desta «marca indelével que molda cada qual por assim dizer contra a sua vontade. O que se chupa com o leite materno» (Maffesoli, 2012, p. 56), que os seres humanos se adaptam ao seu meio. O que, de facto, os comportamentos desviantes em relação às autoridades político-sanitárias nos mostram, é que o ethos social se constitui a partir dos pequenos gestos, dos pequenos rituais e dos hábitos da vida quotidiana, sejam eles perigosos e subversivos.

\section{O CONFINAMENTO, O DISTANCIAMENTO SOCIAL E O ESPÍRITO DE REVOLTA}

O distanciamento social impediu inúmeros grupos sociais de manifestarem publicamente o seu descontentamento, gerando nos indivíduos outras tantas frustrações: «Ao fazer da França uma prisão domiciliária, a crise sanitária silenciou a cólera social» 
(Allard, 2020). Não nos queremos referir à cólera que desemboca nas lutas políticas, lutas essas que podem, é verdade, generalizar-se a todos os sectores da vida económica e social, a curto ou médio prazo: às fábricas, aos transportes, aos hospitais, aos tribunais, à polícia, etc., mas ao instinto de revolta e às manifestações plurais deste instinto, que emanam do povo e que não obedecem a nenhuma palavra de ordem partidária. Estamos na era das revoltas difusas e já não na das revoluções, com os seus projetos e programas, assentes numa teoria elaborada por algum iluminado. E é de facto a existência de uma teoria, de uma ideologia que visa submeter os factos à lógica da ideia, que distingue radicalmente as revoltas, com a sua opacidade e o seu poder destrutivo espontâneo, das revoluções e do cálculo desses «políticos lúcidos, cheios de sangue frio e de sentido prático», elogiados por Lenin (1966, p. 145). A revolta é uma aporia do ponto de vista prático, pois o seu fracasso leva irremediavelmente à reprodução do existente. Porém, tem o mérito de equacionar a possibilidade de uma alternativa à sociedade, para além do estreito arcabouço da teoria revolucionária, de pôr em questão a possibilidade de uma racionalização total da ação humana e de mostrar que o Homem não obedece docilmente às injunções sanitárias, políticas ou económicas, mesmo quando assentes numa base científica, já que estas injunções «não constituem as motivações mais características da alma humana, sobretudo nos períodos em que a emoção religiosa domina» (Bloch, 1964, p. 72).

Ao falarmos de revolta, estamos inevitavelmente a pensar no movimento dos coletes amarelos em França, movimento esse que apresenta flagrantes similitudes com as atuais desobediências civis aos constrangimentos político-sanitários. Em ambos os casos, trata-se de deslegitimar a palavra pública - seja ela oriunda dos peritos em matéria sanitária ou dos profissionais da política - e trata-se também de contestar a hierarquia social existente. É isso que está em jogo nas atuais formas de incivilidade e de indisciplina. É isso que estava em jogo nas ocupações selvagens das rotundas, aos sábados, pelos coletes amarelos em França, como forma de protesto social e mesmo de revolta contra as instituiçôes (o Estado, os bancos, os restaurantes e lojas de luxo, etc.) e contra todos aqueles que as incarnam, à semelhança dos políticos, dos banqueiros, em suma, de todos aqueles que são genericamente categorizados pelo povo como ricos. Ora, os coletes amarelos que, durante um ano, foram quem melhor incarnou o espírito de revolta, 
acabaram reduzidos ao silêncio com as medidas de confinamento e de distanciamento social. Mas as frustrações e os recalcamentos gerados pelo silenciamento da voz do povo poderão conduzir a formas extremas de violência social.

A revolta é uma espécie de «insurreição latente» instalada na cidade, uma «desforra perversa do "íntimo terror" de uma cidade rendida ao fantasma da assepsia social» e também uma «desforra perversa do aborrecimento letal em que a mesma cidade agoniza» (Martins, 2002, p. 5). A revolta remete para formas de relacionamento horizontais, que se opõem à verticalidade das relações hierárquicas que encontramos no Estado, nas empresas, na escola, etc. É «um protesto obscuro que nem envolve sistemas nem razões», como o dizia Albert Camus (1973, p. 134). Essa forma de luta difusa prosseguiu nas redes sociais durante o período do confinamento e do distanciamento social e voltará para a rua quando as circunstâncias o proporcionarem. É que o povo real, de quem Marx (1982, p. 742) dizia, retomando uma expressão de Thomas Hobbes, que é «puer robustus sed malitiosus» (uma criança robusta, mas maliciosa), não faz mais do que reivindicar o que lhe é devido: o direito a uma palavra que lhe foi confiscada; o direito àquilo a que Max Weber chama «democracia de rua», direitos esses que prescindem de toda a forma de representação política.

Foi este instinto de revolta que levou muitos jovens a organizar rodeos com motas nas ruas e em parques de estacionamento, desafiando assim as autoridades policiais. Foi esse mesmo instinto que levou milhares de alemães a protestar na rua contra as medidas ditatoriais do confinamento, com a divisa: «Não façam caso da lei básica» (Freidel, 2020), sendo que o zeloso jornalista alemão, com alguma pobreza de espírito, atribuiu logo esta contestação popular aos grupúsculos da extrema-direita! É ainda este instinto que está a levar novamente os coletes amarelos para as ruas e rotundas francesas, que são o equivalente do Aventino romano, a sede da plebe. O que nos parece característico destas revoltas é a acentuação do tempo presente, como o pressagiou o grande poeta e ensaísta mexicano Octavio Paz, laureado com o Prémio Nobel de literatura em 1990, num livro originalmente publicado em 1969: «O tempo que regressa, se é verdade que vivemos efetivamente um retorno dos tempos, uma revolta geral, não será nem um futuro, nem um passado, mas um presente. (...) O presente não nos projeta em nenhum além, as eternidades multicores do outro mundo ou os paraísos 
abstratos do fim da história, mas projeta-nos na medula, o centro invisível do tempo: aqui e agora» (1971, p. 158, 159).

Colocar a tónica na vivência do tempo presente constitui também uma maneira de integrar a morte no quotidiano, de tomarmos consciência, novamente, do caráter trágico da vida, de nos recordarmos que «a despeito da morte, a vida coletiva perdura» (Maffesoli, 2020b). As palavras proferidas por um dos banhistas da Flórida, recalcitrante a toda a forma de distanciamento social que, muito provavelmente sob a pressão dos média e das autoridades político-sanitárias, veio posteriormente pedir desculpas pelo que disse, inscrevem-se plenamente neste sentimento trágico da vida: «Se tiver que apanhar o corona, apanho-o» (Ortiz, 2020).

\section{A CONTAGIOSA SOCIABILIDADE DO HOMEM}

Para concluir, diremos que o instinto gregário sobrepor-se-á sempre ao egoísmo dos interesses e ao racionalismo dos peritos. Não é só o vírus que se transmite, a alegria de estarmos juntos também o faz, também é contagiosa. Curiosamente, nem a psicologia, nem a filosofia, nem a antropologia, nem a sociologia esperaram pela chegada desta última versão do coronavírus para fazer empréstimos semânticos aos epidemiólogos: Gustave Le Bon e Émile Durkheim referiam-se ao conceito de contágio (de cum-tangere, tocar com, tocar em); Georg Lukacs ao de absorção; Jean Baudrillard ao de viralidade; Edgar Morin ao de possessão; Max Scheler e Michel Maffesoli ao de contaminação. Numa altura em que prevalecem medidas de confinamento e de distanciamento social impostas, as palavras que Victor Hugo escreveu no Prefácio das suas Contemplaçóes ecoam como uma mensagem de bom senso e mesmo de senso comum, um senso comum que sempre foi denegrido pelos intelectuais, fechados na sua torre de marfim: «Ah! Insensato, que acredita que eu não sou você!» (1969, p. 4). 


\section{BIBLIOGRAFIA}

Adorno, Th. W. (1983). Minima Moralia. Réflexions sur la vie mutilée. Paris: Payot.

Alexandre, L., Besnier, J.-M. (2016). Les robots font-ils l'amour ? Le transhumanisme en 12 questions. Paris: Dunod.

Allard, M. d' (2020). La colère sociale amorce son deconfinement. L'bumanité, de 18 de maio de 2020. Consultado em https://www.humanite.fr/la-colere-sociale-amorce-son-deconfinement-689212.

Almeida, S. J. (2020). Costa proíbe a Páscoa e fecha aeroportos. O Público, de 02 de abril de 2020. Consultado em https://www.publico.pt/2020/04/02/politica/noticia/costa-proibe-pascoa-fecha-aeroportos-1910790.

Baudrillard, J. (1987). L'autre par lui-même. Habilitation. Paris: Éditions Galilée.

Bloch, E. (1964). Thomas Münzer, théologien de la révolution. Paris: Julliard.

Boncourt, Th. (2020). Pourquoi la pandémie de coronavirus révèle une crise de l'institution scientifique. Le Journal du Dimanche, de 01 de abril de 2020. Consultado em https://www.lejdd.fr/Societe/Sciences/pourquoi-la-pandemie-de-coronavirus-revele-une-crise-de-linstitution-scientifique-3959171.

Buzzati, D. (2006). Le désert des tartares. Paris: Pocket.

Camus, A. (1973). L’homme révolté. Paris: Gallimard, Collection Idées.

Castro, C. (2020). Marginal da Póvoa e Vila do Conde cheia durante estado de emergência. Jornal de Notícias, de 22 de março de 2020. Consultado em https://www.jn.pt/local/noticias/porto/povoa-de-varzim/marginal-da-povoa-e-vila-do-conde-cheia-durante-estado-de-emergencia-11967708.html.

Coccia, E. (2020). La Terre peut se débarrasser de nous avec la plus petite de ses créatures. Entrevista ao Jornal Le Monde, de 03 de abril de 2020. Consultado em https://www.lemonde.fr/idees/article/2020/04/03/emanuele-coccia-la-terre-peut-se-debarrasser-de-nous-avec-la-plus-petite-de-ses-creatures_6035354_3232.html.

Commolet, C. (2020). Ligue des champions. PSG - Dortmund : une soirée hors du temps aux abords du Parc des Princes. Ouest-France, de 11 de março de 2020. Consultado em https://www.ouest-france.fr/sport/ football/ligue-des-champions/ligue-des-champions-psg-dortmund-une-soiree-hors-du-temps-aux-abords-du-parc-des-princes-6775770.

Comte, A. (1966). Catéchisme positiviste. Paris: Garnier-Flammarion.

Condorcet (1970). Esquisse d'un tableau historique des progrès de l'esprit humain. Paris: Librairie Philosophique J. Vrin.

Defoe, D. (2001). Robinson Crusoé. Paris: Gallimard, Collection Folio Classique.

Dernières Nouvelles d'Alsace (2020). Malgré l'interdiction des attroupements, près de 400 personnes réunies pour un match de foot inter-quartiers. Dernières Nonvelles d'Alsace, de 24 de maio de 2020. Consultado em https://www.dna.fr/sante/2020/05/24/malgre-l-interdiction-des-attroupements-pres-de-400-personnes-se-sont-reunies-pour-un-match-inter-quartiers. 
Duby, G. (1976). Le temps des cathédrales. L'art et la société (980-1420). Paris: Gallimard.

Durkheim, E. (1979). Les formes élémentaires de la vie religieuse. Paris: PUF.

Elias, N. (1989-1990). O processo civilizacional: investigaçôes sociogenéticas e psicogenéticas. 2 volumes. Lisboa: Dom Quixote.

Ferry, L. (2016). La révolution transhumaniste. Comment la technomédecine et l'uberisation du monde vont bouleverser nos vies. Paris: Plon.

Foucault, M. (1975). Surveiller et punir. Naissance de la prison. Paris: Gallimard.

Freidel, M. (2020). Rechtsextreme instrumentalisieren Corona-Demos. Frankfurter Allgemeine Zeitung, de 16 de maio de 2020. Consultado em https://www.faz.net/aktuell/politik/inland/politiker-warnen-vor-rechtsextremen-auf-corona-demos-16773094.html.

Freund, J. (1965). L'essence du politique. Paris: Sirey.

Gonçalves, A. (2020). Nem a morte nos reúne. Communitas Think Tank -Ideias. Braga: CECS. Abril de 2020. [PDF]. Consultado em http://www.communitas.pt/nem-a-morte-nos-reune/. Acesso a 01 de maio de 2020.

Griaule, M. (1966). Dieu d'eau. Entretiens avec Ogotemmêli. Paris: Librairie Arthème Fayard.

Guénois, J.-M. (2020). Les funérailles se réorganisent selon les religions. Le Figaro, de 20 de março de 2020. Consultado em https://www.lefigaro.fr/actualite-france/les-funerailles-se-reorganisent-selon-les-religions-20200323.

Harari, Y. N. (2020). The world after coronavirus. Financial Times, de 20 de março de 2020. Consultado em https://www.ft.com/content/19d90308-6858-11ea-a3c9-1fe6fedcca75.

Hugo, V. (1969). Les contemplations. Paris: Éditions Garnier Frères.

Husson, E. (2020). Aussi inquiétante que le COVID-19, la crise de la raison ? Gourous et boucs émissaires font leur retour. Atlantico.fr, de 20 de março de 2020. Consultado em https://www.atlantico.fr/decryptage/3588284/aussi-inquietante-que-le-COVID-19-la-crise-de-la-raison--gourous-et-boucs-emissaires-font-leur-retour-coronavirus-segolene-royal-elon-musk-professeur-raoult-donald-trump-edouard-husson.

Kracauer, S. (2001). Le roman policier. Paris: Éditions Payot \& Rivages.

Le Figaro (2020). «La rentrée ne sera pas normale», avertit le président du Conseil scientifique. Le Figaro, de 09 de julho de 2020. Consultado em https://www.lefigaro.fr/sciences/coronavirus-la-rentree-ne-sera-pas-normale-avertit-le-president-du-conseil-scientifique-20200709.

Le Nouvel Obs (2020). «On va tous mourir, autant finir en beauté» : en Floride, le «spring break» continue malgré le coronavirus. Le Nouvel Obs, de 19 de março de 2020. Consultado em https:/ /www.nouvelobs.com/ coronavirus-de-wuhan/20200319.OBS26305/on-va-tous-mourir-autant-finir-en-beaute-en-floride-le-spring-break-continue-malgre-le-coronavirus.html. 
Lénine, V. I. (1966). Que faire? Paris: Seuil.

López S. Rivas (2020). Neurociência explica por que temos "fome de pele" e precisamos de abraços. El País-Brasil, de 16 de maio de 2020. Consultado em https://brasil.elpais.com/smoda/2020-05-16/neurociencia-explica-por-que-temos-fome-de-pele-e-precisamos-de-abracos.html.

Maffesoli, M. (2012). Homo eroticus. Des communions émotionnelles. Paris: CNRS Éditions.

Maffesoli, M. (2020a). La nostalgie du sacré. Le retour du religieux dans les sociétés postmodernes. Paris: Cerf.

Maffesoli, M. (2020b). Après le coronavirus, ils rêvent d'un autre monde : le regard sur le futur de Michel Maffesoli. Midi Libre, de 12 de abril de 2020. Consultado em https://www.midilibre.fr/2020/04/12/apres-le-coronavirus-ils-revent-dun-autre-monde-le-regard-sur-le-futur-de-michel-maffesoli,8843615.php.

Mann, T. (1978). La mort à Venise. Paris: Le Livre de Poche.

Martins, M. L. (2002). O trágico na modernidade. Interact - Revista On-line de Arte, Cultura e Tecnologia. [PDF]. Consultado em http://hdl.handle.net/1822/1087. Acesso a 25 de abril de 2020.

Marx, K. (1982). CEuvres. Tome III. Philosophie. Paris: Gallimard, Collection Bibliothèque de La Pléiade.

Menezes, J. de (2020). Police condemn Liverpool fans for celebrating Premier League title win at Anfield. The Independent, de 26 de junho de 2020. Consultado em https://www.independent.co.uk/sport/football/premier-league/liverpool-win-premier-league-police-fans-anfield-merseryside-a9586586.html.

Mitchell, J. (2020). Méfions-nous du doux despote qui veut nous protéger de la mort à tout prix. Le Figaro, de 20 de abril de 2020. Consultado em https://www.lefigaro.fr/vox/monde/joshua-mitchell-mefions-nous-du-doux-despote-qui-veut-nous-proteger-de-la-mort-a-tout-prix-20200420.

Morin, E. (2020). Um festival d'incertitudes. In AA.VV. (2020). Tracts de crises. Um virus et des hommes. 18 mars/11mai 2020. Paris: Gallimard, Collection Tracts Gallimard, pp. 405-418.

Nietzsche, F. (1930). La volonté de puissance. Essai d'une transmutation de toutes les valeurs. 2 tomes. Paris: Mercure de France.

Nietzsche, F. (2013). Ainsi parlait Zarathoustra. Paris: Le Livre de Poche.

Ortiz, A. (2020). Man Who Said, «If I Get Corona, I Get Corona,» Apologizes. The New York Times, de 24 de março de 2020. Consultado em https://www.nytimes.com/2020/03/24/us/coronavirus-brady-sluder-spring-break.html.

Pareto, V. (1968). Traité de sociologie générale. Genève: Droz.

Paz, O. (1971). Conjonctions et disjonctions. Paris: Gallimard.

Péguy, Ch. (1934). Pensées. Paris: Gallimard.

Pessoa, F. (Ricardo Reis) (2003). Prosa. Lisboa: Assírio \& Alvim. 
Pidd, H. (2020). Summer of illegal raves expected in England despite coronavirus crisis. The Guardian, de 15 de junho de 2020. Consultado em https://www.theguardian.com/world/2020/jun/15/summer-of-illegal-raves-expected-in-england-despite-coronavirus-crisis.

Simmel, G. (1979). Métropoles et mentalité. In Grafmeyer, Y., Joseph, I. (1979). L’École de Chicago. Naissance de l'écologie urbaine. Paris: Éditions du Champ Urbain, pp. 61-77.

Simmel, G. (1987). Philosophie de l'argent. Paris: PUF.

Simmel, G. (1999). Sociologie. Études sur les formes de la socialisation. Paris: PUF.

Slimani, L. (2020). L'épidémie de coronavirus vient accentuer une tendance : nous touchons de moins en moins la peau de l'autre. Le Monde, de 03 de Abril de 2020. Consultado em https://www.lemonde.fr/idees/ article/2020/04/03/leila-slimani-l-epidemie-de-coronavirus-vient-accentuer-une-tendance-nous-touchons-

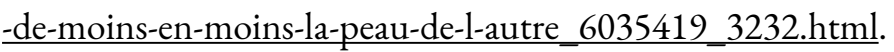

Susca, V. (2016). Les affinités connectives. Sociologie de la culture numérique. Paris: Cerf.

Thomas d'Aquin (1856). Somme théologique. Tome 5. Paris: Librairie de Louis Vivès, Éditeur.

Tournier, M. (1972). Vendredi ou les limbes du Pacifique. Paris: Gallimard, Collection Folio.

Twain, M. (2001). Le journal d'Adam. Pitbook.com [PDF]. Consultado em https://www.pitbook.com/. Acesso a 10 de junho de 2020.

Verne, J. (1979). Vingt mille lieues sous les mers. 2 tomes. Genève: Éditions Famot.

Weber, M. (1965). Essais sur la théorie de la science. Paris: Plon. 